\title{
Institutional Roots of Authoritarian Rule in the Middle East: Civic Legacies of the Islamic Waqf
}

\author{
Timur Kuran
}

Duke University

June 12, 2014

ERID Working Paper Number 171

This paper can be downloaded without charge from the Social Science Research Network Electronic Paper Collection:

http://ssrn.com/abstract=2449569

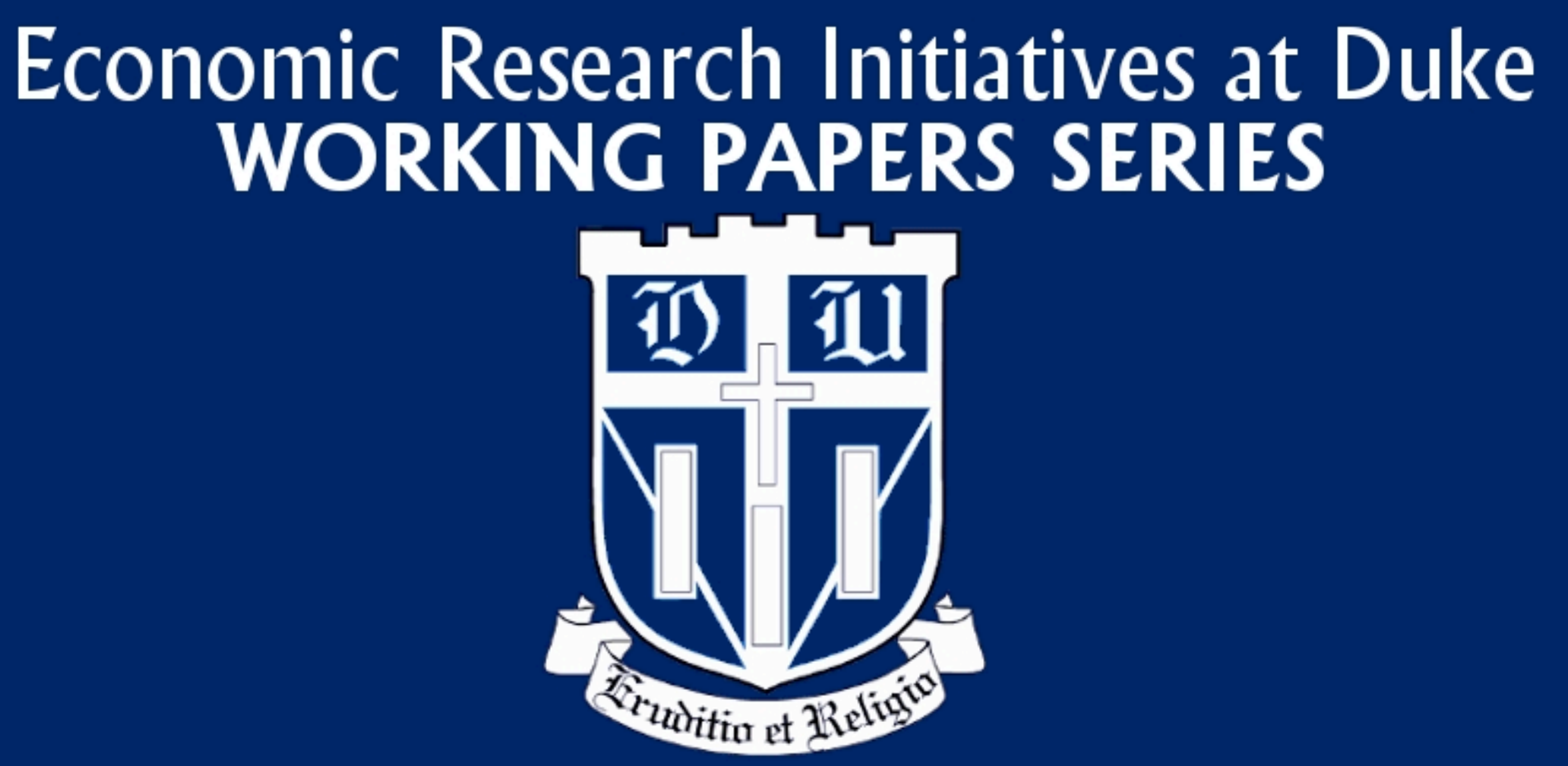




\title{
Institutional Roots of Authoritarian Rule in the Middle East: Civic Legacies of the Islamic Waqf
}

\author{
by Timur Kuran*
}

June 2014

\begin{abstract}
.
In the pre-modern Middle East the closest thing to an autonomous private organization was the Islamic waqf. This non-state institution inhibited political participation, collective action, and rule of law, among other indicators of democratization. It did so through several mechanisms. Its activities were essentially set by its founder, which limited its capacity to meet political challenges. Being designed to provide a service on its own, it could not participate in lasting political coalitions. The waqf's beneficiaries had no say in evaluating or selecting its officers, and they had trouble forming a political community. Thus, for all the resources it controlled, the Islamic waqf contributed minimally to building civil society. As a core element of Islam's classical institutional complex, it perpetuated authoritarian rule by keeping the state largely unrestrained. Therein lies a key reason for the slow pace of the Middle East's democratization process.
\end{abstract}

Keywords: Middle East, Ottoman Empire, Turkey, Arab world, Egypt, Islamic law, sharia, waqf, democracy, autocracy, civil society, political participation, collective action, coalition, corporation, foundation, trust, institutional change.

* Department of Economics, Box 90097, Duke University, Durham, NC 27708, USA (t.kuran@duke.edu)

Acknowledgment. In the course of writing this article, I benefited from discussions with Bruce Ackerman, Luz Marina Arias, Bas van Bavel, Jenna Bednar, Fahad Bishara, Richard Brooks, Jessica Dijkman, Robert Ellickson, Mohammad Fadel, Henry Hansmann, Alexander Kirshner, Jennifer London, Daniel Markovits, Tine De Moor, Nate Oman, David Patel, Claire Priest, Auke Rijpma, Adam Sabra, Jan Luiten van Zanden, and Jaco Zuijderduijn. I am grateful to Noa CnaanOn and Mai Ha Linh Nguyen for research assistance, and to the Economic Policy Research Foundation of Turkey (TEPAV) and the Berkley Center for Religion, Peace and World Affairs at Georgetown University for financial support. 


\section{Introduction}

Even after the Arab uprisings of 2011, the Middle East ${ }^{1}$ remains the world's least democratized region. ${ }^{2}$ The checks and balances within its political regimes are at best unreliable. That is why the region's secularists and Islamists, and also its Shiis and Sunnis, object vehemently to being governed by parties under the other's control.

For all their insights, the literatures on these patterns raise puzzles. ${ }^{3}$ Certain important findings relate to only part of the region. For example, the observation that oil revenues allow rentier states to silence their critics leaves unexplained the persistence of autocratic rule in oilimporting states. ${ }^{4}$ Other popular arguments clash with evidence from other regions. The treatment of the Middle East's low political performance as a legacy of colonialism ${ }^{5}$ raises the question of why many former colonies elsewhere, including India and Brazil, have better political records. A common trait in the literature is a focus on proximate factors. ${ }^{6}$ Since the end of foreign rule, it is commonly observed, monarchs and presidents have emasculated the news media, suppressed intellectual inquiry, restricted artistic expression, banned political parties, and co-opted regional, ethnic and religious organizations. With political advocacy by non-governmental organizations (NGOs) severely restricted, sustained collective action is generally limited to extraordinary circumstances. Moreover, NGOs that overcome obstacles to political action tend to be unaccountable to their constituencies. ${ }^{7}$ But these well-documented patterns do not explain why the oppressive policies in question have been effective for decades on end or why NGOs were weak at the start of the establishment of national regimes. Indeed, neither the colonial period of the Middle East nor its pre-colonial centuries featured NGOs capable of restraining the state.

This article suggests that the patterns in question, including the persistence of authoritarianism, the political passivity of the masses, and the weakness of non-state organizations, are rooted in historical processes that predate European colonialism. Colonial as well as postcolonial political institutions were superimposed on an institutional complex that was poorly suited

\footnotetext{
${ }^{1}$ For present purposes the "Middle East" consists of the 22 members of the Arab League plus Iran and Turkey.

${ }^{2}$ On a standardized 0-10 scale (10 best), the population-weighted Freedom House civil liberties score of the Middle East is 3.1, as against 9.6 for the OECD; and the rule of law index of the World Bank is 3.8 for the Middle East, as against 7.4 for the OECD. In both calculations, Turkey is included in the Middle East and excluded from the OECD.

${ }^{3}$ Diamond 2010, Sarkissian 2012, and Fish 2002 critique the influential explanations.

${ }^{4}$ Ross 2001 shows that oil wealth hinders democratization.

${ }^{5}$ Ismael and Ismael 1997.

${ }^{6}$ The most insightful contributions include Browers 2006, Yom 2005, Langohr 2004, and Wiktorowitz 2000.

${ }^{7}$ Bayat 2002, 8 .
} 
to democratization. My focus is on a key element of that complex: the Islamic waqf. Known in English also as a pious foundation or an Islamic trust, the Islamic waqf is called habous in parts of North Africa and bonyad in Iran. It is a foundation established under pre-modern Islamic law. It differs from the modern waqf, which has emerged in certain countries. ${ }^{8}$

Within the pre-modern Islamic legal system, the Islamic waqf was the closest thing to an autonomous private organization. As such, it might have served as a vehicle for organized political participation, mass collective action, and political accountability, among other indicators of democratization. It might have generated a vibrant civil society capable of constraining rulers and majorities. In fact, the Islamic waqf impoverished civil society and made democratization more difficult. The rest of the article substantiates this claim.

Civil society refers to the collectivity of associations that people form outside the family, the state, and the commercial sector to advance common interests. It has played vital roles in every successful democratization process, which also included the building of checks and balances into the state itself. ${ }^{9}$ To be sure, the specific trajectories differed across today's democratic societies. Beginning their transformations at different times, they also experienced different social cleavages. Their democratic characteristics — enforced human rights, broad political participation through parties and lobbies, autonomous legislatures and judiciaries, universal suffrage — did not develop in lockstep. ${ }^{10}$ Hence, looking at the history of civil society in other societies would not amount to treating them as the only model of political success. The multiplicity of Western political paths suggests that the Middle East could have followed a distinct political path, even several paths unique to sub-regions. For all their differences, the European paths to democracy also have commonalities. They all involved protracted struggles involving perpetual private associations. These struggles taught impoverished, dominated, and relatively poor groups to get organized effectively. All of the paths produced checks and balances of some sort.

Hence, investigating the waqf's political consequences amounts to asking why the Middle Eastern counterpart of European private organizations achieved less power. A fine-grained

\footnotetext{
${ }^{8}$ See sect. 9.

${ }^{9}$ Tocqueville 1835-40-2000 developed the seminal argument. For extensions, see Putnam 1993.

${ }^{10}$ The roles of peasants, cities, and merchants in constraining the monarch all differed across contexts. Although England's Glorious Revolution (1688) and the French Revolution (1789) both instituted checks and balances, the key coalitions differed (Ziblatt 2006, Tilly 2005, Moore 1966).
} 
identification of the waqf's political functions will help also to identify critical obstacles to sustained democratization in the present.

In what follows I argue that the waqf limited democratization through several mutually supportive mechanisms. Its use of resources was set by its founder, which limited its capacity to meet new political challenges. In disregarding the preferences of its beneficiaries, it limited political participation. It could not pool resources with other entities, which kept it from joining durable political coalitions. It limited political participation further by denying its beneficiaries a say in the selection of officers.

In the modern Middle East, the corporation, which is a self-governing organization conducive to politics, has taken over many social functions long performed by the Islamic waqf. Notwithstanding its name that harkens to early Islam, even the modern waqf is a non-profit or charitable corporation. Islamic charities of the twenty-first century tend to be organized as modern waqfs, rather than as Islamic waqfs. This makes it especially useful, in identifying the Islamic waqf's political consequences, to keep an eye on corresponding developments in Western Europe, the region where the corporation first facilitated democratization.

\section{The Islamic waqf and its economic significance}

Under classical Islamic law, which took shape between the seventh and tenth centuries, a waqf was a foundation that a Muslim individual established by turning privately held real estate into a revenue-producing endowment. The endowment was to provide a designated service in perpetuity. Ordinarily a judge (kadi) ratified the waqf's purpose. He also recorded the assets placed in the endowment and the founder's stipulations regarding disposition of the income. The resulting deed (waqfiyya) was meant to govern the waqf's operation forever. ${ }^{11}$

The service could be anything legitimate under Islamic law. Thus, waqfs were commonly established to support mosques, schools, fountains, hospitals, soup kitchens, bathhouses, inns, and funerary complexes. Whatever the particular service, the endowment would be expected to support operational expenses, including repairs and staff salaries. ${ }^{12}$ Sometimes the deed explicitly named the beneficiaries: a particular family, or the indigents of a particular town, or a class of taxpayers.

\footnotetext{
${ }^{11}$ For general accounts of waqf rules and practices, see Barnes 1987, Schoenblum 1999, and Kuran 2001.

12 Certain modest waqfs offered services without any dedicated physical structure. They included those established for paying a neighborhood's taxes, assisting widows, liberating indebted prisoners, or conducting prayers for the dead.
} 
When no beneficiaries were specified, the locational choice might privilege certain communities. The patients of a Damascus hospital would consist disproportionately of Damascenes. Ordinarily the waqf's income was exempt from taxation. ${ }^{13}$

Responsibility for managing the waqf's endowment and implementing its deed fell to a caretaker (mutawalli). The caretaker rented out properties, authorized repairs, hired and supervised employees, and delivered services. He performed these duties as the founder's agent; he was supposed to implement the wishes that the founder expressed through the deed. The initial caretaker of a waqf was selected by the founder, who could specify how his successors would be appointed. Sometimes he would name a sequence of individuals. Another common pattern was to reserve the position for a particular office holder, such as particular mosque's imam. Some founders simply assigned the succession decision to the caretaker. Ordinarily the appointment was for life.

Before modern times, expropriation was common in the Middle East. A waqf enjoyed considerable immunity against confiscation because of the belief that its assets were sacred. ${ }^{14}$ This belief thus served as a credible commitment device. Knowing that a ruler could not confiscate a waqf without appearing impious, people expected him to respect the inalienability of endowed assets. The exceptions generally occurred during regime changes or major internal challenges. Rulers would declare a cluster of waqfs invalid, usually on the ground that the founders had not owned the endowed assets, as waqf law required. The best-known exceptions prove the rule. Mamluk and Ottoman expropriators usually backed down in the face of resistance. On balance, an asset was much less likely to be confiscated if it belonged to a waqf than if it was privately owned. ${ }^{15}$

\footnotetext{
${ }^{13}$ Barnes 1989, 38-40; Leeuwen 1999, 53-54.

${ }^{14}$ The sacredness belief was reinforced through waqf deeds, which typically stated that anyone who harms a waqf will suffer both in the afterlife (Öztürk 1995, 23).

${ }^{15}$ Lev 2005, 155; Leeuwen 1999, 88-89, 96; Behrens-Abouseif 2002, 64-66; Irwin 1986, 96, 141; and Yediyıldız $1982,161$.
} 


\begin{tabular}{|c|c|c|c|c|c|}
\hline Source & Place & Date & $\begin{array}{l}\text { Tax revenue } \\
\text { accruing to } \\
\text { waqfs }\end{array}$ & Waqf assets & $\begin{array}{c}\text { Estimation } \\
\text { method }\end{array}$ \\
\hline Ubicini 1853 & Turkey & 1800 & & $\begin{array}{l}\text { Three-quarters of } \\
\text { landed property }\end{array}$ & $\begin{array}{l}\text { Aggregation of } \\
\text { official opinions, } \\
\text { reports }\end{array}$ \\
\hline $\begin{array}{l}\text { Behrens- } \\
\text { Abouseif } \\
2002\end{array}$ & Egypt & 1517 & & Half of land & $\begin{array}{l}\text { Ottoman land } \\
\text { survey }\end{array}$ \\
\hline Berque 1974 & Algiers & 1830 & & $\begin{array}{l}\text { Half of buildings } \\
\text { in city }\end{array}$ & $\begin{array}{l}\text { French land } \\
\text { survey }\end{array}$ \\
\hline $\begin{array}{l}\text { Deguilhem } \\
2004\end{array}$ & $\begin{array}{l}\text { Damascus } \\
\text { and } \\
\text { environs }\end{array}$ & 1922 & & $\begin{array}{l}\text { More than half of } \\
\text { real estate }\end{array}$ & $\begin{array}{l}\text { Impressions of } \\
\text { historians }\end{array}$ \\
\hline $\begin{array}{l}\text { Barkan and } \\
\text { Ayverdi } 1970\end{array}$ & Anatolia & 1530 & $27 \%$ & & $\begin{array}{l}\text { Statistical } \\
\text { sampling }\end{array}$ \\
\hline $\begin{array}{l}\text { Yediyıldız } \\
1984\end{array}$ & Anatolia & $\begin{array}{c}1601- \\
1700\end{array}$ & $26.8 \%$ & & $\begin{array}{l}\text { Statistical } \\
\text { sampling }\end{array}$ \\
\hline Öztürk 1995 & Anatolia & $\begin{array}{c}1801- \\
1900\end{array}$ & $15.8 \%$ & & $\begin{array}{l}\text { Statistical } \\
\text { sampling }\end{array}$ \\
\hline
\end{tabular}

Table 1. Waqf assets or revenues: Estimates

The relative security of waqf property steered resources into waqfs. Although no comprehensive data set exists, various indicators testify to their vast economic significance. First of all, practically every monograph on a pre-modern Middle Eastern city devotes at least a chapter to local waqfs, invariably establishing that they played critical economic roles. Second, the available estimates of waqf assets and income involve huge figures (Table 1). The three studies using statistical sampling show that the share of tax revenue accruing to Anatolian waqfs was 27 percent in the $1530 \mathrm{~s}, 26.8$ percent in the seventeenth century, and 15.8 percent in the nineteenth century. ${ }^{16}$ The Ottoman treasury received about half of its tax revenue from real estate; poll taxes and opportunistic taxes (avarlz) formed the other major categories. Hence, until the nineteenth century, which marked the start of fundamental reforms, waqfs claimed around half of all imperial real estate taxes. The dip in the nineteenth century reflects the nationalizations that accompanied

\footnotetext{
${ }^{16}$ Barkan and Ayverdi 1970, 17; Yediyıldız 1984, 26; Öztürk 1995, 54.
} 
the reforms; they are discussed below. A third indicator is that waqf-related cases appear very frequently in court records. Of 9,074 commercial cases in a judicial data base of seventeenthcentury Istanbul, 17 percent concerned a waqf matter. By contrast, a state official was involved in just 7.6 percent of the cases. ${ }^{17}$ Finally, a large majority of all surviving Middle Eastern buildings from before the nineteenth century were financed through a waqf. The main exceptions are palaces, fortresses, and harbors.

Their huge asset base made waqfs potentially powerful political players. They might have used their resources to constrain the state on behalf of the beneficiaries whom they were supposed to serve. In the process, the nucleus of a civil society capable of advancing political objectives might have emerged. The resulting decentralization of power could have placed the Middle East on the road to democratization.

In charge of an organization commanding income-producing assets, a waqf caretaker was usually esteemed for that reason alone. He was the natural leader of his waqf's constituency - the teachers and students of a school, the poor who depended on a soup kitchen, or the community living near a particular fountain. ${ }^{18}$ With each such constituency, the caretaker provided a focal point for coordinating individual demands. Hence, every waqf constituency formed a community potentially capable of collective action. Insofar as waqf beneficiaries worked collectively to advance their joint interests, they might have developed the organizational, communicational, and strategic skills to pursue collective action in other contexts and through different groups. Waqfs could have turned the Middle East into a region hospitable to initiatives requiring social organization, in other words, a region rich in "social capital."19 Such initiatives could have included campaigns to influence state policies. However, as we shall now see, the waqf was designed to inhibit collective action by sub-communities, not to facilitate it.

\footnotetext{
${ }^{17}$ Kuran 2010-13.

${ }^{18}$ A common theme in historical accounts of Middle Eastern cities involves the esteem enjoyed by waqf caretakers (Behar 2003, 65-83; Leeuwen 1999, ch. 4). In court records they carry an honorific title, which points to the institutionalization of their elevated social status.

${ }^{19}$ A rich literature treats social capital as fundamental to economic development. See Banfield 1958, ch. 5-8; Coleman 1990, ch. 12; Fukuyama 1995, 3-57; Putnam 1993; and Guiso, Sapienza, and Zingales 2008. On the Middle East specifically, see Jamal 2007, especially ch. 6.
} 


\section{Origins of the waqf's political features}

Nothing is certain about the waqf's origins except that it is not among Islam's original institutions. The Quran does not mention it, which suggests that it had not yet emerged by Muhammad's death in 632. ${ }^{20}$ Although numerous remembrances about early Islam (hadīth) hold that Muhammad's companions formed waqfs, these accounts were probably concocted to legitimize an addition to the Islamic institutional complex. ${ }^{21}$

Institutions resembling the waqf were present in pre-Islamic civilizations of the Middle East. In the Sassanid and Byzantine empires temples had long been financed through some form of trust. $^{22}$ In all likelihood, the idea of endowing assets to provide a permanent service was appropriated from these empires during Islam's expansion into Syria and Iraq. ${ }^{23}$ The administration of the Umayyad Empire (661-750), and then that of the Abbasid Empire (7501258), drew liberally on the talents of bureaucrats who had served other states. ${ }^{24}$ Under both dynasties the consolidation of power involved higher taxes on various groups, with exemptions provided to accommodate political pressures. These policies bred insecurity among administrative cadres. Although a talented person could prosper by serving an Umayyad or Abbasid caliph, he was always at risk of being fired, expropriated, even executed; a misjudgment or a rumor could make him lose everything suddenly.

The resulting insecurity would have fueled a quest for institutions capable of alleviating the risks in question. The debated alternatives are evident in the earliest compendium of waqf rules, al-Khassaf's ninth-century Kitāb ahkām al awqāf. ${ }^{25}$ According to this treatise, the waqf entered the Islamic institutional complex in the eighth century. Apparently the principle of freezing the use of waqf assets in perpetuity drew clerical opposition. The rules that emerged from the negotiations were legitimized through late-appearing recollections of Muhammad's life. Collectively they gave powerful constituencies a stake in the waqf. State officials obtained material security through the right to shelter wealth from unpredictable rulers. Religious officials (ulamā) gained access to rents through their supervisory authority. As for rulers, officials would serve them

\footnotetext{
${ }^{20}$ Oberauer 2013.

${ }^{21}$ Hâtemî 1969, 29-38. During Islam's first few centuries leading scholars dismissed hundreds of thousands of such recollections as apochryphal. Modern investigators consider most of the remainder fabricated (Brown 2011).

22 Thomas 1987.

${ }^{23}$ Köprülü 1931. Yıldırım 1999 shows that in certain respects the waqf and the Byzantine "pious foundation" developed in parallel, influencing one another.

${ }^{24}$ On the Middle East's political evolution during this period, see Lapidus 1988, ch. 3-8.

${ }^{25}$ For an English translation, see Verbit 2008.
} 
more willingly; they themselves would obtain insurance against a palace coup through the ability to shelter wealth for their own families and descendants; and, finally, waqf-supplied social services would reflect well on their regimes. The achieved agreement allowed the ruler and his aides alike to establish socially beneficial waqfs in return for secure control over their assets and the right to keep some of their income.

From the eighth century onward, some of the largest waqfs were established by members of the ruling dynasty. Known as imperial waqfs, they include the Complex of Sultan Barquq in Cairo (1384) and the Süleymaniye Complex in Istanbul (1557). ${ }^{26}$ Relatives of a sultan formed imperial waqfs as insurance against loss of intra-dynastic influence. The mother of the crownprince could want an autonomous financial base in case her son died prematurely or was outmaneuvered by a rival claimant. An imperial waqf also provided security against changes in state priorities. By virtue of its sacredness, a waqf built in the name of Sultan Süleyman II would endure even if his descendants spurned its objectives.

Two waqf characteristics, both already mentioned, betray that the benefits of forming a waqf were expected to accrue primarily to high officials and their families. The immovability requirement favored state officials, who were paid primarily through land grants. This restriction discriminated against merchants, whose wealth consisted of movable goods. Not until the sixteenth century did merchants secured the ability to shelter liquid wealth, and then only in Anatolia and the Balkans. ${ }^{27}$ The requirement that the founder be a Muslim also favored political elites, most of whom were Muslim by birth or conversion. Exceptions were made for strategically valuable nonMuslims, who could form a functionally similar organization.

The claim that the waqf favored landowning Muslim elites goes against a huge literature that treats it as an expression of pious charity. ${ }^{28}$ But it is consistent with the lack of restrictions on non-Muslims with regard to the use of waqf services. Ordinarily Christians and Jews were eligible to use waqf-maintained fountains and stay in waqf-funded inns. True, they were unwelcome in mosques, unless they intended to convert; and waqf founders could restrict services to Muslims. However, the resulting consumption exclusions reflected in-group biases that infused daily life rather than a requirement of waqf law. A Muslim could establish a waqf for the benefit of a non-

\footnotetext{
${ }^{26}$ A waqf complex typically included a mosque plus several charities.

${ }^{27}$ Mandaville 1979.

${ }^{28}$ Leading examples include Lev 2005 and Singer 2002.
} 
Muslim neighborhood. Also telling is that non-Muslims freely used another Islamic institution that absorbed private capital: the Islamic partnership. An Islamic partnership's capital had to be liquid, and it served short-lived cooperative ventures. ${ }^{29}$ Its unsuitability to sheltering wealth explains why Christians and Jews, banned from forming waqfs, were allowed to form legally supporterd commercial ventures (Table 2).

Various specifics of Islamic law accord, then, with the waqf's emergence as a wealth shelter for high state officials and their families. Although some officials participated in commerce, their wealth was concentrated in real estate. In adapting pre-Islamic models of the trust creatively, they gave themselves the lion's share of the gains. There is evidence that they continued to benefit disproportionately up to the modern era. In the eighteenth century, 42.7 percent of all Anatolian waqfs were founded by state officials, and an additional 16 percent by clerics generally allied with the sultan. ${ }^{30}$ Because officials formed the largest waqfs, the disproportion was even greater in relation to control of waqf assets.

The Umayyad and Abbasid sultans who consented to the law of the waqf must have understood that it raised the likelihood of challenges from officials. To dampen waqf-based threats, they would have restricted the uses of waqf assets. Several rules discussed in sections ahead served that objective: the requirement to follow the founder's instructions, the courts' duty to monitor waqf operations, and obstacles to waqf mergers. It mattered that many high officials were foreignborn slaves. ${ }^{31}$ Their status enhanced rulers' ability to eliminate those who posed a threat.

\begin{tabular}{|ccc|}
\hline & Islamic waqf & Islamic partnership \\
Faith of founder & Must be Muslim & Unrestricted \\
Type of investment & Real estate & Currency \\
\hline
\end{tabular}

Table 2. Restrictions on the two main investment instruments of Islamic law

\footnotetext{
${ }^{29}$ Kuran 2011, 48-52, 59-68.

${ }^{30}$ Yediyildız 1990, 121-22.

${ }^{31}$ Goodwin 1994; Pipes 1981.
} 
This interpretation is consistent with recorded correlations between the "democratic deficit" of the modern Middle East and the diffusion of the Islamic institutional complex. Highlighting the reliance of Muslim sultans on slave armies, Lisa Blaydes and Eric Chaney (2013) find that this pattern of military recruitment caused Middle Eastern rulers to lag behind west European rulers in legitimacy. In related work Chaney (2012) identifies a positive relationship between the share of a country's landmass that early Muslim armies conquered and its present democratic deficit. Insofar as pre-modern military recruitment affected modern politics, the influences would have operated through the entire institutional complex associated with slave armies. As both works underscore, foreign-born slave soldiers had difficulty forming coalitions with disgruntled local groups. However, slave soldiers and their descendants came to control enormous wealth. Besides, the families of slaves often got assimilated into local communities. These two factors would have undermined the objective of keeping officials loyal to the sultan. The reliance on slave soldiers required, then, the adoption of measures to inhibit the formation of opposition movements. Because of its indefinite life, the most pertinent institution was the waqf. Under the adopted rules, the waqfs of slave soldiers would have kept the ruler's power unchallenged. ${ }^{32}$

Islamic legal discourses customarily distinguish between the charitable waqf (waqf khayrī), which serves a broad constituency such as a neighborhood or the poor, and the family waqf (waqf $a h l \bar{l})$, which provides income to a family. In practice, these legal categories represented the ends of a continuum. Many family waqfs devoted some income to a public service. As for charitable waqfs, typically they benefited the founder's family disproportionately; thus, their caretaker often belonged to the founder's line. ${ }^{33}$ For his services a caretaker received a fixed salary, or a proportion of the waqf's revenue, or its residual revenue after mandatory expenses were met; hybrid patterns were not uncommon. ${ }^{34}$ As Table 3 shows, family waqfs were typically minuscule, which is consistent with the objective of limiting autonomous power centers. The third canonical category

\footnotetext{
${ }^{32}$ Another politically critical element of the institutional complex was the bundling political and religious authority (Rubin 2011 and Lewis 1993, ch. 21). Still another consisted of rules that kept businesses atomistic (Kuran 2013).

${ }^{33}$ Local social norms determined the dividing lines between family waqfs and charitable waqfs.

${ }^{34}$ For deeds involving a fixed salary, see, in Kuran 2010-13, Istanbul 3 (1618), 31b/4, 85b/1, 62a/2; Istanbul 9 (1662), $167 \mathrm{~b} / 1$; and for a stipulation of residual income, Galata 41 (1617), 36b/3. Baer 1969, 80, refers to salaries proportional to the endowment. For examples of all payment patterns, see Öcalan, Sevim, and Yavaş, editors, 2013 (fixed 361; proportional 190, 378, 388, 415, 556; residual 397, 550; hybrid 455, 479).
} 
is the imperial waqf, mentioned above. Its endowment could consist of imperial real estate that was granted to the founder expressly to finance a waqf.

Ready to address how the waqf hampered democratization, we will consider several characteristics that shaped civic patterns. For each, we will draw attention to historical continuities.

\begin{tabular}{|lcccc|}
\hline & Family waqf & Charitable waqf & Imperial waqf \\
Source of endowment & $\begin{array}{c}\text { Muslim individual } \\
\text { outside ruling family }\end{array}$ & $\begin{array}{c}\text { Muslim individual } \\
\text { outside ruling family }\end{array}$ & $\begin{array}{c}\text { Member of ruling } \\
\text { Muslim dynasty }\end{array}$ \\
Recorded beneficiaries & $\begin{array}{c}\text { Founder's family } \\
\text { and descendants }\end{array}$ & $\begin{array}{c}\text { Constituency much } \\
\text { broader than } \\
\text { founder's family }\end{array}$ & $\begin{array}{c}\text { Large constituency } \\
\text { outside of ruling } \\
\text { dynasty }\end{array}$ \\
Size of endowment & Typically very small & Highly variable & Usually large \\
\hline
\end{tabular}

Table 3. Three categories of waqfs: Main properties

\section{Limits on self-management}

By design the waqf was a rigid organization. In its canonical form, its assets were inalienable; never sold, bequeathed, pawned, or transferred, they were to finance its activities forever through steady rental income. The services were to be delivered in perpetuity according to instructions in the deed. Thus, a waqf-financed school was to teach designated subjects through an indicated number of teachers. The deed would also identify real estate whose income would cover the waqf's expenditures, including staff remuneration and maintenance. ${ }^{35}$

The ideal presumed that a complete contract is feasible. It also posited a static world with fixed relative prices, technologies, and preferences. For instance, land values would never change in ways that might prevent the financing of the stipulated services. The ideal also presumed that the judge ratifying the deed would evaluate assets accurately; that he and his successors would

\footnotetext{
${ }^{35}$ For deeds with detailed stipulations, see Istanbul 4 (1619), 54b/1, in Kuran 2010-13; Leeuwen 1999, 128-30; and Öcalan, Sevim, and Yavaş, editors, 2013, 360-63, 406-7, 550-1.
} 
monitor caretakers flawlessly; and that successive caretakers would manage waqf assets competently.

Nevertheless, it was understood that conditions relevant to the waqf's usefulness might change. To limit inefficiencies, the architects of waqf law allowed founders to pre-authorize specific modifications. Accordingly, a school's waqf deed could permit the caretaker to swap an asset for a substitute. It could also allow the construction of new classrooms in case of need. But legitimate changes were limited to those explicitly allowed. If the deed permitted one asset swap, once that option was exercised, the waqf's properties became strictly inalienable. Sooner or later, every waqf obeying classical law would become frozen. ${ }^{36}$ Incentives would arise along the way to circumvent restrictions through extra-legal means. The resulting corruption had long-term political consequences of its own, though they lie outside this article's scope. ${ }^{37}$

As significant as the operational restrictions on the caretaker is what he was not required to deliver. He was not obligated to meet any efficiency target. Thus, a caretaker in charge of a school was not expected to reach some threshold of educational performance, such as reading proficiency by a particular age. He was accountable to the founder alone, and the courts, not students or their parents, judged whether he was meeting the founder's wishes. Whatever the type of waqf, the preferences of the founder trumped those of the end users. For their part, the intended beneficiaries were not expected to participate in governance. They were to consume services passively.

Actual waqfs enjoyed greater managerial discretion because the waqf deed was necessarily an incomplete contract. Unavoidably it gave the caretaker some discretion. Through creative interpretations, a caretaker could make adjustments that the founder could not have even contemplated. Any given adjustment might well accord with the spirit of the founder's objectives. By the same token, discretion could lead to choices that the founder would have ruled out, had he been able to imagine future circumstances.

\footnotetext{
${ }^{36}$ Some waqf deeds authorized the founder to make unlimited changes. But this flexibility ended with his death. For examples, see Istanbul 4 (1619) 31b/3; 23 (1696), 51 b/2; Galata 224 (1713), 82a/1, all recorded in Kuran 2010-13; and. Leeuwen 1999, 145.

${ }^{37}$ See Kuran 2001, 869-75, 883-87.
} 


\section{Curbs on political participation}

The many varieties of democracy all emphasize broad political participation, which is achieved through such means as town meetings, referenda, lobbies, protests, opinion polls, and elections. The masses participate in governance through choices at the ballot box, but also by voicing preferences and ideas, working with like-minded citizens within advocacy organizations, and linking their future votes to the performance of their elected officials. Such grass-roots politics contributes to shaping public discourse. It also helps to make governance reflect the popular will.

Another characteristic feature of democracy is mandatory information sharing. Although even the most transparent democracies conceal sensitive data such as defense strategies and health records, their officials are required to report periodically about their activities. Moreover, many government decisions, including government budgets, are debated in public. Whether the typical citizen learns about the intricacies of public policies is beside the point. ${ }^{38}$ For the system to serve the electorate better than any practical alternative it may suffice to have a few citizens follow any given issue. ${ }^{39}$ A common problem is that political players distort information self-servingly, confusing even citizens intent on staying informed. Democracies try to limit information pollution by standardizing disclosure requirements.

The rules of the Islamic waqf promoted neither broad political participation nor transparency in governance. Authority to execute the waqf deed belonged to a single person, though he might have had subordinates. Apart from the courts, no one, not even his staff, was entitled to information about assets, income, expenses, or service quality. The consequent lack of transparency facilitated modifications that he wanted; it also hindered those that he opposed. ${ }^{40}$

Ordinarily, the deed itself was public knowledge, which generated expectations concerning services. People living near a fountain counted on access to running water, because typically a plaque publicized its endowment. If water stopped running, residents could sue the caretaker; and if the court found the caretaker negligent, it might dismiss him. Examples exist of lawsuits brought by displeased beneficiaries against a caretaker. ${ }^{41}$ But to make a convincing case aggrieved

\footnotetext{
${ }^{38}$ On widespread voter ignorance even on fundamental policies, see Caplan 2007 and Zaller 1992.

${ }^{39}$ Dahl 1989, ch. 16.

${ }^{40}$ A tradeoff between governance quality and decision-making costs exists whenever there are multiple stake holders (Buchanan and Tullock 1962, ch. 8).

${ }^{41}$ Hoexter 1998, ch. 5; Gerber 1988, 166-69; Leeuwen 1999, 159. See the following adjudications in Kuran 2010-13: Istanbul 3 (1618), 84a/1; Istanbul 9 (1662), 250b/2; Galata 130 (1683), 55a/5; Istanbul 22 (1695), 80b/2; Istanbul 3 (1696), 32b/1.
} 
beneficiaries could not simply make a show of frustration. They had to prove that the deed was being violated. Because information concerning the waqf's finances and actions were not public knowledge, beneficiary-launched lawsuits against caretakers were rare. Out of 1544 waqf-related lawsuits in a seventeenth-century Istanbul sample, only six entailed an accusation of caretaker mismanagement. None involved a plaintiff who was also a beneficiary. In all six, the plaintiff was an active or former waqf official privy to inside information. ${ }^{42}$

In any case, the right to complain was no substitute for formal accountability to beneficiaries through periodic disclosures. Some judges were prepared to overlook improprieties in return for bribes. If the judge was in collusion with the caretaker, yet another option was to report both to higher authorities. That risked alienating officials capable of retaliation. Indeed, the fear of retaliation made people refrain from suing state officials unless their case was exceptionally strong. ${ }^{43}$ Court fees alone could deter a lawsuit. In practice, then, a waqf's beneficiaries had only a limited sway over its caretaker's actions. Although capable of preventing egregious mismanagement, they could not ensure his good will, let alone his competence.

Every waqf defined a group of beneficiaries who formed a potential political entity. Whether they developed a group identity was not assured. The users of an inn on a trade route could remain mutual strangers for years. The rules of the waqf did nothing to enhance group consciousness among co-beneficiaries without reason to interact anyway. And even where a group identity formed naturally, as with the users of a fountain, there was nothing to turn them into a political community. The residents of a modern city know that they form a political community because they vote periodically to select a mayor. The beneficiaries of a waqf, even if they developed a group identity, would not necessarily become a political community.

The consequent sense of powerlessness would have discouraged beneficiaries from trying to influence policies relevant to their welfare. They would also have refrained from seeking information about possible alternatives. Accepting what came their way, and withholding feedback from service suppliers, they would have become accustomed to passive consumption.

One indication of the powerlessness of waqf beneficiaries lies in the tenure of caretakers. In the Anatolian town of Sivas, 1902 waqf caretakers were replaced between 1700 and 1850. No fewer than 74 percent of the replacements followed a death in office. In the remaining cases, the

\footnotetext{
${ }^{42}$ The cases are in Kuran 2010-13.

${ }^{43}$ Kuran and Lustig 2012, 649-52, 659.
} 
successor was typically the retiring caretaker's son. A caretaker's performance had to slip severely for a challenge; and only occasionally did a firing occur. One Sivas caretaker was replaced by his son when he became deaf; another was dismissed when he could no longer perform one of his major duties, which was to read the Quran. ${ }^{44}$ Poor financial management alone rarely resulted in dismissal. $^{45}$

Remember that rulers would have sought to keep the privilege to shelter wealth in waqfs from facilitating political opposition. Each of the above-discussed limitations on mass participation would have suited the ruler's survival strategy. Leaving waqf beneficiaries ignorant about management promoted stability by keeping waqfs from becoming foci of discontent. The passivity expected of beneficiaries limited mass political activity. It also reduced the capacity of the masses to react effectively to economic downturns, military defeats, and other such misfortunes. In the absence of pre-existing consumer organizations and lacking experience in organized collective action, disgruntled subjects had to start organizing from scratch. As for the caretaker's lack of accountability to end users, it would have dampened expectations of official accountability in other domains. Requiring the caretaker to deliver periodic public reports would have set precedents for inclusive governance generally. The instituted rules thus helped to keep political power centralized by preventing potentially subversive communities from getting organized. They served as an instrument of authoritarian governance.

Students of participatory politics distinguish between tame and rebellious organizations. ${ }^{46}$ In barring waqfs from political advocacy, Islamic law ruled out the latter type. But it reduced participation even further by denying even the beneficiaries of tame waqfs a hand in management. This constriction would have impoverished public discourse on social services. The masses would also have failed to develop the habits and skills needed to communicate thoughts, expectations, and grievances concerning social services.

An immediate unintended consequence would have been a reduction in the efficiency of existing waqfs. Over the longer-term institutional innovations would have slowed. The pace of innovations is correlated with the number of ideas in circulation. That is why metropolises, which bring together diverse people, contribute to knowledge advancement far beyond their population

\footnotetext{
${ }^{44}$ Demirel 2000, 127-31.

${ }^{45}$ Leeuwen 1999, 135, reports cases from eighteenth-century Damascus. Each involved a major waqf.

${ }^{46}$ Fung 2003, 534-36.
} 
shares ${ }^{47}$ In excluding the masses from politics, the rules of the waqf would have diminished the production of ideas for change and reduced institutional creativity broadly, across the social system. ${ }^{48}$ Awareness of shared problems would also have diminished. For both reasons, long-term political development would have suffered, along with economic development.

\section{The waqf vs. its European counterparts}

The properties of the waqf may be contrasted with those of the corporation, whose use spread in western Europe as the waqf gained popularity in the Middle East. The comparison will be useful because it is in western Europe that democracy emerged, providing standards by which regimes are now measured.

Of the factors that fueled the rise of the first democracies, one was that social services were delivered through a rich mix of organizations that allowed the decentralization of political power, sustained collective action by what we now call NGOs, and the formation of durable coalitions across interest groups. The corporation was part of the organizational mix, and its significance expanded during the Middle Ages and beyond.

A corporation is an association established under some law; claiming collective authority in a particular domain, it has legal personhood and a perpetual existence independent of its membership. Although its decisions may rely on the entire membership, ordinarily certain officials hold the reins. With regard to the selection of officials, various options exist. The officials themselves may appoint their successors. Alternatively, the general membership may participate in the selection. Precisely because a corporation is self-governing, it may modify its own rules. Hence, its management patterns present bewildering variety.

Figure 1 depicts several organizations used to provide social services. The horizontal axis represents the organization's discretion regarding asset management and service delivery. The vertical axis represents the share of its beneficiaries and officials who participate in its decisions. At one extreme, decisions are made by a single person; at the other, every official and beneficiary participates. Of the four organizations depicted, $\mathrm{W}^{\mathrm{I}}$ represents a canonical Islamic waqf: required to follow the founder's directions, its limited discretion is exercised by two people, the caretaker

\footnotetext{
${ }^{47}$ Glaeser 2011, ch. 1, 9.

48 This accords with slower urban growth in the Middle East than in western Europe between 800 and 1800 (Bosker, Buringh, and van Zanden 2013).
} 
and a judge. $\mathrm{C}$ represents a corporation, which differs by design along both dimensions. It has greater managerial flexibility, and more individuals participate in its decisions. As shown in figure 1 , the default for a corporation is complete autonomy. In practice, a corporation has a charter that defines a mission. If its purpose is education, it cannot provide poor relief. Its mission and management may be constrained also through its founding charter. State-imposed covenants may compound the restrictions. ${ }^{49}$

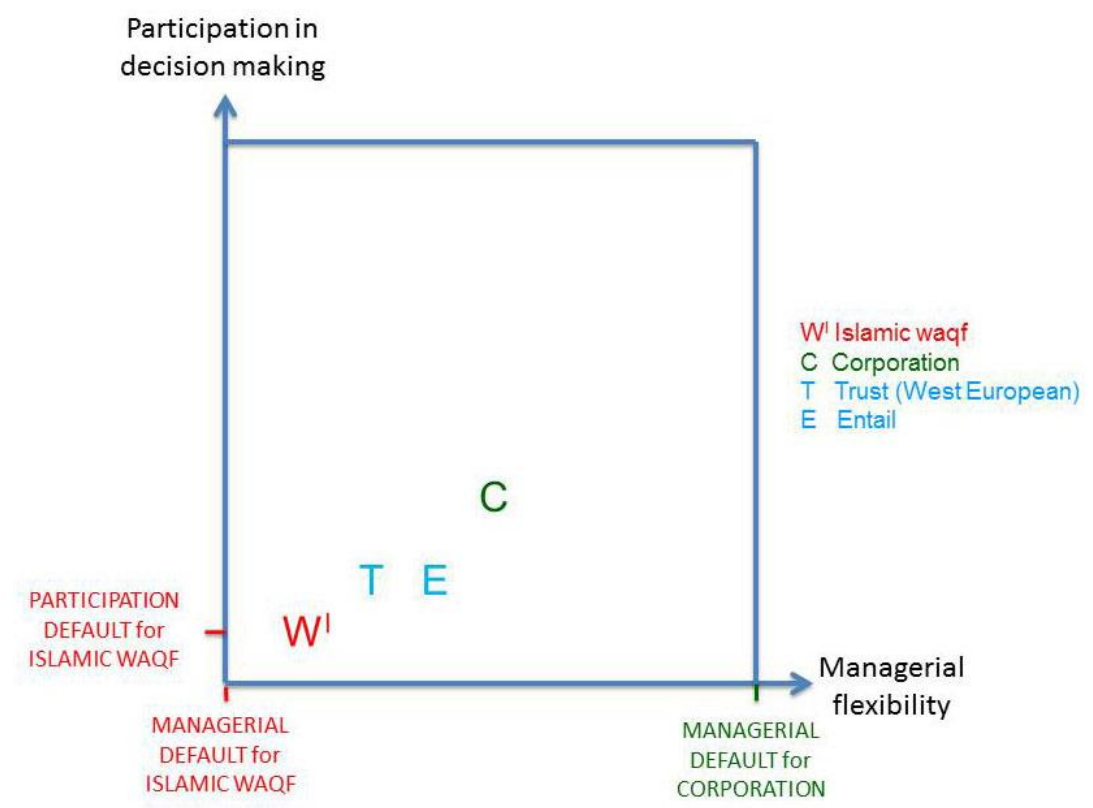

Figure 1. Managerial flexibility and participation in decision making:

Islamic waqf vs. corporation, trust, and entail

A medieval European university established as a corporation had greater managerial flexibility than a waqf-supported madrasa. ${ }^{50}$ The figure captures the relationship, in that $\mathrm{C}$ lies to the right of $\mathrm{W}^{\mathrm{I}}$. Some European corporations, including guilds, involved the broad membership in its decisions. Others assigned authority to professionals delivering services. At a university, for instance, the curriculum was set by professors and administrators; students were not consulted. At a waqf-maintained school even fewer people were involved: the caretaker and perhaps also a judge. The vertical coordinates of $\mathrm{C}$ and $\mathrm{W}^{\mathrm{I}}$ indicate that more people participated in a corporation's decisions than in those of an equivalent waqf.

The difference in managerial default conditions need not have mattered at the outset. That is because the respective founders could have accommodated the prevailing conditions. The

\footnotetext{
${ }^{49}$ Hansmann 1981.

${ }^{50}$ Makdisi 1981.
} 
difference in question would have mattered as evolving conditions presented situations unimaginable earlier. ${ }^{51}$ The corporation could have exercised options that might have been shut if foreseen. By contrast, the waqf could not even exercise options that the founder would have granted happily.

Whereas in the Middle East the waqf was the only organizational form available for the private provision of public goods, in Europe alternatives existed to the corporation. From the early Middle Ages, social services were supplied also through organizations similar to the waqf. Indeed, hospitals and soup kitchens were often established as a trust, known also as a foundation. Like a waqf, a trust was designed as an inflexible organization with set rules. The uses of its assets were pre-determined, usually to prevent their diversion to unintended uses. For all their similarities to waqfs, European trusts were relatively more pliable. They were not as committed to upholding the wishes of the founder. ${ }^{52}$ Provided cumbersome procedures were followed, their assets could be directed to new uses, even liquidated. In 1526, officials of a Dutch hospital established as a trust travelled to Rome for permission to take over a monastery's assets. ${ }^{53}$ European trusts also made decisions more democratically. This is because they could be administered by boards of trustees rather than a single caretaker. In Figure 1, the location of T, our prototypical trust, reflects the observation that trusts were generally more flexible and more democratic than waqfs. Tlies below $\mathrm{C}$ because ordinarily trust beneficiaries were excluded from governance. ${ }^{54}$

Yet another European vehicle for providing social services was the entail. Like the Islamic family waqf, the entail sheltered wealth for a family and its descendants. Creditors could not touch entailed assets; generally, neither could the state. This made it particularly popular in times of weak property rights. As with a waqf's founder, that of an entail could direct expenditures from the grave. Nevertheless, the entail was less rigid than the waqf. Depending on the region, the founder's authority was limited to between two and four generations. Eventually his descendants could use the assets freely. Also, an entail was revocable through an agreement of its living

\footnotetext{
${ }^{51}$ Zanden 2009, ch. 2; Moor 2008; and Greif 2006, chs. 3, 10 explain how this organizational adaptability contributed to Europe's economic ascent.

${ }^{52}$ Rijpma 2012 ch. 2, especially 54.

${ }^{53}$ Regional archive of Leiden 503, no. 212 (based on communication with Auke Rijpma). The hospital was itself established by a religious order.

${ }^{54}$ At least in the Middle Ages, no sharp distinction existed between the trust and the corporation. Because their characteristics could be combined, their practical differences were of degree rather than kind (Rijpma 2012, 30-33).
} 
beneficiaries. Decision making within an entail was also relatively more democratic. ${ }^{55}$ More than one beneficiary participated in its management. Thus, in Figure $1 \mathrm{E}$ lies above $\mathrm{W}^{\mathrm{I}}$ and to its right.

In sum, two of the organizational options for providing social services in pre-modern Europe, the trust and the entail, had waqf-like features, but they were less rigid. In any case, there was an additional option that differed fundamentally from the waqf. Whereas the waqf bestowed governance privileges primarily on the founder, the corporation allowed self-governance by living beneficiaries. Thus, Europe provided social services through organizations that were more adaptable as well as more democratic.

None of the above interpretations imply that the waqf's political effects were uniformly negative. Consider again the case of political participation. Although limited participation closes political possibilities, it has advantages, too. Reducing the number of decision makers can speed up the process and lessen the danger of gridlock. Such benefits can swamp the losses from being unable to fine tune services to beneficiary preferences. It is possible, then, for a single caretaker to provide a waqf service more efficiently than a committee. That is the logic underlying the separation of beneficiaries and management in modern charitable corporations. Consider Doctors without Borders, which cares for victims of disasters and wars. Its managerial team forms a tiny fraction of its benefactors and beneficiaries.

But there is a critical difference between Doctors without Borders and a hospital established as an Islamic waqf. The former can shift its operations easily between regions; it can also adapt its surgical teams and procedures to new technologies. Although its board of directors may disagree on details, generally favored modifications will be made. For its part, the waqf hospital is unhampered by the challenges of achieving group consensus; if the caretaker needs to convince anyone, it is a single judge. By the same token, the deed of his waqf limits his discretion. For one thing, the founder will have situated the hospital, precluding its relocation. For another, the caretaker cannot adjust expenses just because of technological advances, even with support from the intended beneficiaries.

Critical here are the political consequences of the regional differences in organizational options. For reasons outlined, the West's broader menu was more conducive tocivic participation in governance, and hence to democratization, than that restricted to the Islamic waqf.

${ }^{55}$ Zuijderduijn 2011. 


\section{Obstacles to forming coalitions}

Waqfs need not have pursued activities in mutual isolation. They could have formed coalitions with an eye toward maximizing their joint influence. Just as European cities worked together to limit royal taxes, so waqfs could have mobilized to advance their common interests and address their shared grievances. And just as urban communities produced rationales for local administration, waqf-based coalitions might have generated ideologies partial to their beneficiaries. In the millennium preceding Europe's early democracies, diverse corporate entities, including universities and guilds, contributed to institutionalizing constraints on monarchs. ${ }^{56}$

However, for all their wealth and the status their caretakers, waqfs did not participate in politics. Their rigid managerial rules kept them from using resources for political purposes. In any case, they were envisaged as apolitical organizations. Thus, whereas an incorporated European church was free to participate in politics, a waqf-based mosque was not. And whereas European cities formed coalitions, waqfs within the same city did not cooperate among themselves, to say nothing of forming political blocs across cities. Indeed, there emerged no federation of madrasas, or association of fountain operators, or confederation of diverse waqfs. The lack of ties among waqfs reduced their already compromised capacity to constrain sultans. Unlike Europe's politically vocal universities, municipalities, and professional associations, they did not contribute to democratization.

The inability to pool resources at will limited the political potential of waqfs also through the waste it generated. If a waqf's founder had not explicitly allowed it to work with other organizations, achievable economies of scale or scope would remain unexploited. Services that a single large waqf could deliver most efficiently-road maintenance, piped water-would be provided at high cost by multiple waqfs. Founders were free to authorize transfers to a large waqf. But such resource pooling required an unlikely coincidence of goals between the feeder waqf and the receiving waqf. ${ }^{57}$ Moreover, the coincidence had to be predictable. The founder of a fountain in 1500 had to foresee the water distribution technologies of the Industrial Age.

One must distinguish between a group-endowed waqf and a merger of separately established waqfs. Neither kind of pooling was common. Mergers of existing waqfs were

\footnotetext{
${ }^{56}$ Berman 1983, ch. 12; Reynolds 1997, ch. 2, 9.

57 Çizakça 2000, 48. Vanity must also have limited pooling. A founder eager to be remembered as a philanthropist would want to keep his waqf from being swallowed up by a larger waqf.
} 
discouraged because of obstacles to ascertaining that the founders would have accepted the terms. Consider two adjacent schools. Merging their waqfs could economize on administrative overhead. But would the founders have agreed to combine classes in one building and rent the other for additional income? If the schools were kept separate and administrative overhead shared, what if one needed more repairs? Would the founder of the better constructed school have endorsed the merger had he foreseen the other's maintenance needs? Because such questions were unanswerable, many potentially beneficial mergers were not even considered. Consequently, when new technologies generated once unimaginable economies of scale, pre-existing waqfs continued to operate independently.

The foregoing logic would not apply to waqfs established simultaneously. Suppose that three property owners decide simultaneously to found a school. They could agree to future mergers under certain conditions and record them in their respective deeds. But synchronized waqf founding was uncommon. Moreover, because Islamic law required the founder to be an individual property owner, the trio could not merge their resources from the start. The rationale for the latter requirement probably lay in rulers' aversion to private coalitions - the very consideration that excluded the corporation from Islamic law in the first place. In any event, restricting the number of founders set a pattern that lasted a millennium. Rifaah al-Tahtawi, an Egyptian thinker of the nineteenth century, wrote that "associations for joint philanthropy are few in [Egypt], in contrast to individual charitable donations and family endowments." 58

The near-absence of resource pooling opportunities kept waqfs with common needs from campaigning jointly for external resources. Consider the caretaker of an educational waqf who finds that her school's supplies are being pilfered. Although she could petition state officials for protection, she could not found an association to advocate better protection for all schools. Waqf regulations barred her from combining forces with the caretakers of other waqfs suffering from theft. Each caretaker faced the state alone.

Nothing in Islamic law keeps individual beneficiaries from working together to prevent theft. Parents from multiple neighborhoods could form a delegation to request better policing. However, this was unlikely in the absence of leadership from caretakers. The hindrances to collective action in large groups would generally block cooperation here, too. Isolated constituencies do not easily gain consciousness of potential gains from cooperation. Nor do they

\footnotetext{
${ }^{58}$ Quoted by Cole 2003, 229.
} 
develop a common political identity. Moreover, beneficiaries who somehow notice the gains from joint action will be unmotivated, as individuals, to incur the setup costs. ${ }^{59}$ For all these reasons, waqf-related petitions to sultans rarely came from groups representing multiple waqfs. Actions were initiated either by lone individuals or by groups concerned about a single waqf. ${ }^{60}$

Just as cooperation was lacking within sectors, it was absent for the waqfs of any given locality. Imagine a school, hospital, and a fountain, all serving a neighborhood through separate waqfs. The caretakers and beneficiaries of these waqfs have a common interest in developing the neighborhood's infrastructure. Yet, they could not combine their resources to campaign for better roads. They had to act independently.

\section{The twilight of the Islamic waqf}

Along with political consequences, the Islamic waqf's inflexibilities had economic consequences. ${ }^{61}$ The economic costs rose over time for existing waqfs, and by the nineteenth century organizations unable to adapt to new technologies looked glaringly inefficient. Among intellectuals, merchants, and bureaucrats, the Islamic waqf came to be seen as an anachronism. ${ }^{62}$ Meanwhile, wide-ranging economic reforms got under way as a matter of state survival. As part of the reforms, Ottoman and Egyptian administrators started building new state institutions to provide social services long supplied privately. The required resources were to come chiefly from the nationalization of waqfs. In earlier times, the sacredness of the waqf would have denied rulers that option. The now common view that the waqf was poorly suited to an economy in motion allowed statesmen to confiscate assets that were beyond the reach of their predecessors. In waves, nationalizations continued in the twentieth century.

The formation of new waqfs had already fallen precipitously. One reason lies in the strengthening of property rights in response to pressures from European businesses and from the beneficiaries of expanding trade with the West. ${ }^{63}$ As arbitrary expropriations fell, the demand for

\footnotetext{
59 Olson 1971, chs. 1-3, 5 .

${ }^{60}$ Even such cases were rare. Out of 1544 waqf-related cases in Kuran 2010-13, 26 involve charges of caretaker mismanagement. In most, the plaintiff is a subsequent caretaker or a beneficiary named in the deed. In only one case (Istanbul 9 (1662), 274b/2) does the plaintiff consist of a group of beneficiaries.

${ }^{61}$ Kuran 2001, 861-69; Kuran 2011, ch. 6.

${ }^{62}$ For accounts of nineteenth- and early twentieth-century thinking on the waqf, see Öztürk 1983, 140-51 for Turkey and Sékaly, 1929, 402-54, 601-59 for Egypt.

${ }^{63}$ Kuran 2011, chs. 10-12.
} 
wealth shelters followed suit. ${ }^{64}$ Another factor is that new means emerged for securing wealth, including ones conducive to accumulation. Publicly traded companies and banks began to absorb savings that had flowed into family waqfs. ${ }^{65}$

The appeal of waqfs was dented also by new instruments for funding charity. In the midnineteenth century it became possible to establish, under special laws, corporations to provide services such as education, water supply, and healthcare. Thus, municipalities took on the functions of urban waqfs; and semi-official agencies, such as the Red Crescent, assumed responsibility for emergency aid and poor relief. Monarchs themselves started forming charitable organizations outside of waqf law. By the early twentieth century, legal transplants enabled the forming of non-profit corporations through simple procedures. Private parties took to establishing perpetual NGOs to deliver social services more flexibly than through waqfs. ${ }^{66}$

Nationalization drives were launched on the pretext that public bureaucracies could fulfill the wishes of waqf founders more reliably. Thus, a "Ministry of Waqfs" was established in Istanbul in 1826, and in Cairo shortly thereafter. ${ }^{67}$ These agencies were supposed to keep separate accounts for the thousands of waqfs under their control. But in stages the assets became part of a fungible resource base. ${ }^{68}$ The nationalization of waqf assets was accompanied by a transfer of its functions to service providers modeled after western archetypes, such as municipalities. Meanwhile in Iran, where waqf nationalization followed a distinct trajectory, the result was the same. By the twentieth century many waqf assets had passed to the state or individuals. ${ }^{69}$

The road not taken in the nineteenth century was to transform the Islamic waqf itself. Emerging problems might have been handled through a reinterpretation suited to changing economic conditions; or by creating new waqf categories for sectors, such as urban water delivery, where greater flexibility was particularly desirable. Reforms would have required working with clerics ('ulamā'), who tended to be conservative and were identified with stagnant parts of the economy. Because clerics controlled the lion's share of waqf assets, reformers opted for initiatives

\footnotetext{
${ }^{64}$ In the Ottoman Empire, the practice of arbitrary expropriation was abolished in 1838 (Findley 1980, 145-46). Thereafter property rights strengthened. In Egypt, the process was more rapid (Baer 1962, 1-70; 1969, 62-74).

${ }^{65}$ Kuran 2011, 161-64, 251-53.

66 Özbek 2002 documents the institutional transformation of charity in Turkey. On Egypt, see Ener 2003, 1-25; Abdelrahman 2004, chs. 4-6.

${ }^{67}$ As in several other Arab countries, in Egypt a Ministry of Waqfs remains in operation. In Turkey, the administration of nationalized waqfs was downgraded to a directorate in 1924, as part of efforts to exclude Islam from public life.

${ }^{68}$ On the Ottoman transformation, see Öztürk 1995, 63-107, 379-471; and on the Egyptian reforms, Baer 1969, 7992.

${ }^{69}$ Çizakça 2000, 141-57.
} 
that would shrink the holdings of waqfs. In keeping existing waqfs rigid, the reformers compounded the troubles that fueled their unpopularity.

The reformers' inclination to modernize waqfs was dampened also by opportunities to improve the provision of social services without taking on Islamic laws and norms. By the early twentieth century, the corporation, a transplanted institution, became the basic delivery vehicle for various services historically provided through Islamic waqfs.

\section{Emergence of the modern waqf}

More than a century after the first wave of assaults on the waqf, it has been reborn in a more flexible form. The name is the same, and some of its promoters tout its Islamic origins. Yet in Turkey, Kuwait, the United Arab Emirates, and even theocratic Iran, it operates under rules fundamentally different from those of the pre-modern era. In legal texts the new institution is called "new waqf" or "civil law waqf," to distinguish it from its historical namesake. ${ }^{70}$

A modern waqf can be formed by a group, whose members may include organizations. It can accept donations and run fundraising campaigns. It may invest in liquid assets, such as equities. It is directed by a board of trustees rather than a single caretaker. Whereas traditionally only the caretaker had standing before the courts, the modern waqf enjoys legal personhood, which enables it to sue and be sued as a legal entity. Merit plays a greater role in the selection of its administrators, who do not appoint their own successors. A modern waqf must issue financial reports periodically. It has managerial flexibilities denied to its Islamic namesake. It can dissolve itself or recast its objectives. ${ }^{71}$ Figure 3 illustrates the differences.

Most critical here, the modern waqf can engage in politics. Although it cannot endorse political parties, it may express opinions on policy issues. It can organize conferences, issue publications, give awards, and make grants, all to influence political outcomes. It can pursue such endeavors in cooperation with other entities, including other waqfs. ${ }^{72}$

\footnotetext{
70 Turkish law refers to "waqfs formed according to Turkish civil law" (Demir 1998, 89; my translation). The Iranian Constitution of 1911 transferred waqf law into the nascent civil code, with a relaxation of traditional requirements. Under the Islamic Republic of Iran, a radically new waqf law has been instituted. Under this law, a waqf is a legal entity and it can manage its assets through a joint-stock company (Çizakça 2000, 149-52, 157-68).

${ }^{71}$ For relevant Turkish statutes, see Demir 1998, 60-65, 67-68, 76-77, 79-80, 119-21, 128-37, 159.

${ }^{72}$ For surveys of various reforms, see Çizakça 2000, ch. 4, and Pioppi 2007.
} 


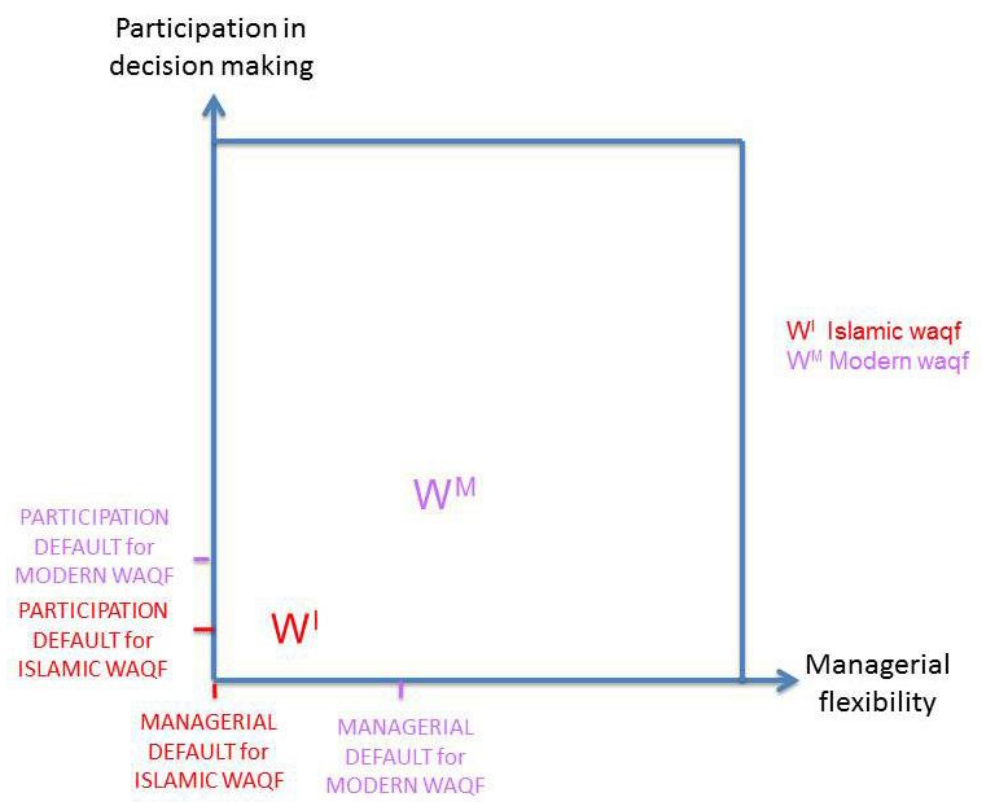

Figure 3. Managerial flexibility and participation in decision making:

Islamic waqf vs. modern waqf.

Just as the caretaker of an Islamic waqf had to follow the founder's stipulations, so a modern waqf's trustees must abide by directives of their founders. But there is no longer a presumption that the waqf deed constitutes a complete contract. A modern waqf's board is authorized to change services, procedures, and goals without outside interference. It is charged with maximizing the overall return on all assets, subject to inter-temporal tradeoffs and the acceptability of risk. The permanence of any particular asset is no longer an objective in itself. The board may judge that the waqf's substantive goals requires a payroll cut in order to finance repairs. Another innovation is that the board plays an integral role in determining how goals are served. To preserve an obsolete hospital merely out of deference to a founder's preferences would be considered irresponsible. All these observations hold irrespective of the political and religious preferences of the founders. They apply to essentially secular modern waqfs such as the Antalya Culture and Art Vakıf (AKSAV), whose activities include Turkish film festivals, but also Islamist modern waqfs, such as the Fatih Youth Vakıf in Istanbul, which promotes Islamic education. ${ }^{73}$

Even in Egypt, where autocratic regimes from 1952 to 2011 nationaled nonreligious waqfs and placed religious waqfs under state supervision, Waqfs are administered in subordination to the wishes of bureaucrats. For that reason, surviving Egyptian waqfs have metamorphosed into

\footnotetext{
${ }^{73}$ https://www.facebook.com: AKSAV; http://fgv.org.tr/.
} 
organizations distinct from their former selves, into what are best called "government waqfs." Because their loss of autonomy is well understood, no more than ten new Egyptian waqfs are formed each year, mostly to support mosques and burials.

If Egypt lacks modern waqfs of the Turkish variety, it is not for lack of motivation. Due to tight supervision, Egyptians wishing to supply nongovernmental social services generally establish foundations (mu'assasat), which are charitable corporations governed under an NGO law of $2002 .^{74}$ Although foundations are also subject to political pressures, at least they can move resources around and raise funds continuously from multiple sources, including both natural and legal persons. Only a single modern non-governmental organization bearing the word "waqf" it its name has been founded in Egypt. This is the Waqfeyat Al-Maadi Community Foundation, which funds local development in poor Cairo neighborhoods and lobbies for better public education. ${ }^{75}$ It was established in 2007 to revive a tradition of social solidarity (takāful) through waqfs, under modernized rules. The founder received special permission to use "waqf" in its name. ${ }^{76}$ Dozens of other foundations formed under the 2002 NGO law (or its successors) characterize themselves as waqf informally, even as they operate under modern legislation. Examples include seven Cairo foundations of Mohamed Al Fangary, most of which assist students at religious schools. ${ }^{77}$

In countries where the modern waqf exists, it carries much less importance in daily life than the Islamic waqf once did. It is not the primary vehicle for social services, which are supplied largely by corporations. The consumers of these services help to determine their characteristics and longevity. With services supplied through private corporations, market choices favor certain suppliers over others. For instance, parents choose among private schools depending on the quality of education. In the case of public corporations, at least in places with some form of local democracy, consumers can punish poor performance at the ballot box. The availability of alternatives to the modern waqf motivates waqf officers to keep them flexible. Competition makes them conscious of the consumer needs, if only to stay relevant.

The modern waqf has not overcome all obstacles to organizational efficiency. As with other organizational forms, free riding may leave consumers insufficiently informed. Vested interests

\footnotetext{
74 This law and its successors recognize two types of NGOs: community development associations and civic foundations. The difference is that the former has at least ten founders (http://www.icnl.org/research/library/files/Egypt/law84-2002-En.pdf). The law makes no reference to the waqf.

${ }^{75} \mathrm{http} / / /$ waqfeyatalmaadi-cf.org/en/index.php.

${ }^{76}$ Atia 2013, 89-90.

${ }^{77}$ El Daly, 73-74. See also Atia 2013, ch. 4.
} 
may render officials unresponsive to the wishes of beneficiaries. The threat of retaliation may silence potential critics. Nevertheless, there is a fundamental difference in accountability between the caretakers of Islamic waqfs and the officials of modern service providers, including those of modern waqfs. In the Middle East today suppliers are essentially expected to serve the end consumer. In the premodern Middle East, the consumer was expected to be a passive recipient of goods provided in perpetuity by elites.

\section{Persistence of historical political patterns}

The differences between the now largely extinct Islamic waqf and its modern namesake raise the question of whether the former matters to current civic life. Might the Islamic waqf be irrelevant to modern Middle Eastern politics? In fact, the region's pre-modern civic patterns got reproduced, to one degree or another, in its modern organizations. Low political participation and limited organizational autonomy have endured even as the region's nation-states acquired the trappings of modern political life, such as parties, elections, and constitutions embodying basic human rights.

The literature on modern Middle Eastern civil society is replete with observations that mirror the historical accounts above. For example, in an influential 2002 article Asef Bayat writes: "Many NGO advocates have complained about the absence of a spirit of participation in the NGOs. ... Paternalistic NGOs perceive their beneficiaries more as recipients of assistance than as participants in development. ... It is not the place of beneficiaries to question the adequacy and quality of services or the accountability of NGOs." 78

One of the mechanisms accounting for the endurance of the Islamic waqf's legacy involves links between civil society and kinship ties. The very process that held down civil society would keep kinship ties strong. The inability to obtain protection against the state by developing autonomous organizations would make people seek security from kin. It would keep alive primordial attachments based on ties of blood, race, language, region, or religion, and even strengthen them in times of social unrest. ${ }^{79}$ It would induce individuals to keep their wealth within the family by doing business through family-owned enterprises. Exchanges would remain largely personal. Cousin marriages would provide another vehicle for preserving family ties in the absence

\footnotetext{
${ }^{78}$ Bayat 2002, 17-18.

${ }^{79}$ Fukuyama 1995, chs. 7-12.
} 
of reliable private organizations that transcend kinship. All such responses to weak civil society suppress generalized trust - the readiness to cooperate and engage in civic endeavors with fellow citizens. ${ }^{80}$

Indicators of civil society have been changing in Middle East, which is consistent with the transformation of greater civic life and weakening kinship ties with urbanization. But the Middle East still has the world's highest consanguineous marriage rates. The rate is 20.5 percent in Turkey, 24.5 percent in Iran, and 35.0 percent in the Arab world, as compared with under 11 percent for the whole world. ${ }^{81}$ It also has conspicuously low generalized trust. On a 0-200 scale, where 100 indicates that half of all people trust others, the generalized trust score for the Middle East is 37.3, as against 67.5 for OECD. ${ }^{82}$

A complementary factor is that the void created by the demise of Islamic waqfs was filled largely by state agencies. Organized hierarchically, they have tended to execute orders issued from the top, showing little responsiveness to the citizenry. Although the reformist leaders responsible for their creation understood that keeping the population content served political stability, they sought above all to overcome the institutional weaknesses responsible for Western domination. ${ }^{83}$ Their objections did not require democratic organizational governance. In any case, the absence of a legacy of mass participation in service provision tempered expectations. Low political participation thus got transplanted to modern organizations.

Not all functions of the Islamic waqfs passed to state agencies. Under new laws of association that began that began to be instituted before World War I, modern NGOs took on expanding roles. These organizations have included charitable associations, trade unions, chambers of commerce, and professional associations, generally organized as some form of corporation. ${ }^{84}$ Autonomous to one degree or another, and empowered to change with the times, they began to instill in individuals the skills of self-governance that Islamic waqfs failed to impart, including strategic planning, public relations, consensus building, coalition formation, and

\footnotetext{
${ }^{80}$ Stolle 2002, Fukuyama 1995, Putnam 1993.

81 (http://ccg.murdoch.edu.au/consang/www.consang.net/global_prevalence/tables.html). See also Tadmori et al. 2009.

82 Turkey is included only in the Middle East. The population-weighted scores are derived from values surveys conducted between 1995 and 2009. Ten Middle Eastern countries are included: Algeria, Egypt, Iran, Iraq, Jordan, Kuwait, Lebanon, Morocco, Saudi Arabia, and Turkey (http://www.jdsurvey.net/jds/jdsurveyMaps.jsp?Idioma= I\&SeccionTexto=0404\&NOID=104).

${ }^{83}$ Lewis 2001, chs. 3-4; Marsot 1984, chs. 7-8.

${ }^{84}$ Hatemî 1979, 58-318; Yener 1998, 9-49; El Daly 2007, 119.
} 
collective negotiation. As such, modern NGOs have contributed, from a low base, to building civil society.

The earliest Middle Eastern charitable organizations established outside the Islamic waqf sector were not necessarily "non-governmental," if by that we mean lack of government direction. During the first decade of the Republic of Turkey (1923-33), the top three charitable organizations as measured by mass participation and fundraising were the Red Crescent Society, the Children's Protection Society, and the Turkish Aviation Society. They pursued government-shared goals and did not seek to restrain the state in any way. Lack of accountability to the citizenry is another feature that these organizations shared. Though formally autonomous, each was a GONGO-a government-organized non-governmental organization. ${ }^{85}$

In Egypt, various NGOs were formed in the early twentieth century in reaction to foreign cultural influences. Eschewing a political identity, many of them subordinated themselves to the government. Over subsequent decades, governments encouraged NGOs, but only if they remained apolitical and allowed state officials to control the selection of leaders, members, and activities. Under Gamal Abdel-Nasser (1956-70), Egyptian NGOs became appendages of the state bureaucracy. No fewer than 60,000 NGO employees received a government salary. A 1964 law authorized the state to close down any NGO that refused to cooperate with the regime.An even harsher NGO law was adopted in $1999 .{ }^{86}$

In the early twenty-first century states by and large continue to control NGOs. Organizations established privately without state guidance are susceptible to state capture. Consider Egypt, where, by 2006 there existed about 31,000 officially registered NGOs, along with a few dozens of advocacy NGOs disguised as law offices to minimize state interference, and hundreds of unregistered NGOs. ${ }^{87}$ Some of these private organizations had been infiltrated by government agents; others were being persecuted. Under the circumstances, they could not expose government corruption or mobilize public outrage at the perpetrators. Most NGOs had agreed implicitly to respect the government's red lines with respect to criticism. Only superficially did they monitor or restrain the state.

\footnotetext{
${ }^{85}$ Çapa 2009, 52-59; Sarıkaya 2011, 58-67; Baytal 2012, 6-69.

${ }^{86}$ Abdelrahman 2004, 120-50.

${ }^{87}$ Abdou, Atia, Hussein, Kharas, and Maaty 2011, 3. In 1991, the number was 12,832 (Al-Sayyid 1993, 231).
} 
Revealingly, NGOs played marginal roles in the Egyptian uprisings of 2011-13. The revolution that ended Mubarak's thirty-year rule was dominated by youths without any history of cooperation. ${ }^{88}$ Although high youth participation was unprecedented, the absence of NGOs was nothing new. They played no key role in prior regime changes. Military officers initiated Egypt's secession from the Ottoman Empire in the 1800s, and their successors overthrew the monarchy in 1952. Another striking characteristic of both the Mubarak and post-Mubarak periods is the lack of collaboration among NGOs. Just as Islamic waqfs were barred from forming coalitions, successive Egyptian regimes have generally discouraged cooperation among NGOs in order to block avenues for mass mobilization. The exceptions have involved strictly economic or social projects with goals complementary to those of the government. ${ }^{89}$

Turkey has substantially more private organizations, which accords with its better political performance than other predominantly Muslim countries of the Middle East. ${ }^{90}$ In 2005 it had 71,240 active associations (94 per 100,000 people, as against 36 for Egypt) and 4,367 modern waqfs (6 per 100,000 people as against none for Egypt). ${ }^{91}$ Nevertheless, participation in civic life is muted by the standards of advanced democracies, as is support for their work. This is reflected in Table 4, which is based on data of the World Alliance for Citizen Participation (CIVICUS). According to this table, in Turkey participation in civic activities is at the OECD average. However, political participation is strikingly low, as is philanthropy used here in the sense of organized philanthropy. Consequently, civil society is relatively ineffective. Turkey's figures generally exceed those for the Arab League, which accords with political comparisons above.

Proximate reasons for Turkey's relatively poor civic performance include decades of restrictive legislation. A deeper factor is the absence of a tradition of mass involvement in organized philanthropy or political activism. As in the past, the vast majority of people assist close kin and neighbors. Few are accustomed to participating in organizations working toward shared social goals, or even to support them financially. People exhibit a preference for individual-toindividual giving over organized collective giving. ${ }^{92}$

\footnotetext{
${ }^{88}$ Carapico 2012.

${ }^{89}$ Yom 2005.

90 On a standardized 1-10 scale (10 best), Turkey's scores on the clean government index of Transparency International, the World Bank Rule of Law index, and the Freedom House civil liberties index for 2011-12 are 4.2, 5.3, and 7.0, respectively. The corresponding Arab League figures are 2.8, 3.5, and 4.4.

${ }^{91}$ Bikmen 2006, 14.

${ }^{92}$ Çarkoğlu 2006, 98-108. El Daly 2007, 158-67, observes the same pattern in Egypt.
} 


\begin{tabular}{|ccccc|}
\hline & $\begin{array}{c}\text { Participation in } \\
\text { civic activities }\end{array}$ & Philanthropy & Policy dialogue & $\begin{array}{c}\text { Political } \\
\text { participation }\end{array}$ \\
Arab League & 0.36 & 0.30 & 0.31 & 0.39 \\
Iran & - & 0.28 & 0.22 & 0.28 \\
Turkey & 0.55 & 0.20 & 0.67 & 0.39 \\
$\begin{array}{c}\text { OECD } \\
\text { (except } \\
\text { Turkey) }\end{array}$ & 0.55 & 0.45 & 0.76 & 0.67 \\
\hline
\end{tabular}

Table 4. Four indices of civic life, 2013: The Middle East and OECD

Source: CIVICUS Enabling Environment Index 2013 (http://civicus.org/eei). The Arab League and OECD indices are population-weighted averages of the member country figures. "Participation in civic activities" provides the percentage of people who say they "have done" or "might do" any of three suggested activities: signing petitions, joining boycotts, attending peaceful demonstrations. "Philanthropy" captures the propensity of people to get involved in "formal charitable activities." Finally, "policy dialogue" assesses the openness of institutional processes to civil society organization inputs. It is derived from variables such as the extent to which "there a network of cooperative associations or interest groups to mediate between society and the political system," and the degree to which "the political leadership enables the participation of civil society in the political process."

These patterns are legacies of Turkey's institutional history. When organized philanthropy was limited to Islamic waqfs, giving was necessarily individual-to-individual for all but a few. Under the circumstances, the individual skills needed for a vigorous civil society failed to develop.

\section{The Long Shadow of the Middle East's Civic Past}

Theories of why the Middle East is the world's least democratized region often point to coalitions among families in control of critical resources, military officers who share in the spoils, and businesses sheltered from competition. Well-organized vested interests do indeed suppress basic freedoms and rig elections. But by themselves they fail to explain why the masses have endured dictatorship for so long. After all, every region of the world, including those now home to democracies, has featured coalitions designed to monopolize political power. ${ }^{93}$ Why did enforceable rules to prevent extreme concentrations of power not take hold in the Middle East?

\footnotetext{
${ }^{93}$ North, Wallis, and Weingast 2009, show that every "open access order," which allows a broad set of personal and associational freedoms, emerged from a "natural order," in which a ruling clique suppresses freedoms.
} 
Reflecting on this question leads inexorably to civil society. What, does civil society lack in the Middle East that is present in advanced democracies? NGOs are not missing; they exist in the tens of thousands. Nor are the prevailing laws keeping private organizations too small or too rigid. For at least a century, the organizational forms formed by private groups in advanced democracies have been available in the Middle East, too. True, the region's authoritarian states keep NGOs from using their capabilities to the fullest. But this returns us to the initial puzzle. If in some countries NGOs have managed to extend and protect their legal rights, what has stood in the way in the Middle East?

The Middle East's distinct institutional history kept its NGOs persistently weak, limiting their ability to restrain authoritarian rule. Although the region's legal systems now support private corporations, the Islamic legal system, until modern times the basis for the region's governance, greatly restricted the organizational options of private groups. Necessarily organized as a waqf, NGOs could not be used for political advocacy. Islamic waqfs limited society's ability to constrain arbitrary rule also through their rigidities, their inability to enter into coalitions, and their lack of accountability to their beneficiaries. Civic life was impoverished. Skills critical to the effectiveness of civil society, such as the capacity to solve collective action problems privately and the ability to form perpetual private coalitions, remained undeveloped.

The remarkable expansion of civil society in the Middle East has been accompanied, in some places, by the waqf's rebirth as a modern organizational form akin to the charitable corporation of the West. If no advanced democracies have followed, it is because of the region's longstanding tradition of civic passivity. Limiting participation in civic organizations, and their political effectiveness, this passivity has also facilitated their capture by the state.

Thus, the proximate factors that have made authoritarianism the Middle Eastern political norm rest on longstanding historical patterns. In the modern era oppressive coalitions have been able to establish entrenched autocracies because the region's masses entered it with stunted political capabilities. These capabilities depend on the organizational skills, civic concerns, and expressive capabilities that individuals acquire as part of their socialization. They depend also on precedents regarding civic engagement. In both these respects, the Middle East has faced handicaps that have constrained, and still constrain, its political development. Patterns of political passivity were carried from pre-modern to modern organizations by people socialized in communities with political habits formed in an earlier age. 
The vicious circle that long kept the Middle East politically authoritarian has mutated, then, but not disappeared. Before the modern reforms that enabled the formation of flexible nongovernmental organizations, the lack of waqf autonomy kept civil society weak; in turn, the weakness of civil society hindered the generation of alternatives to founder-controlled, rigid organizations. Thus, politically effective private organizations could not be founded; absolutist rulers faced no challenges from below; ideologies supportive of structural reforms failed to emerge; and political checks and balances did not arise. Since the emergence of new organizational alternatives outside of government, these constraints have all weakened, but generally not enough to support transitions to self-sustaining democracies. The requisite organizational capabilities take time to develop, as do the social norms that support them. 


\section{Bibliography}

Abdelrahman, Maha M. 2004. Civil Society Exposed: The Politics of NGOs in Egypt. Cairo: American University in Cairo Press.

Al-Sayyid, Mustapha K. 1993. “A Civil Society in Egypt?” Middle East Journal 47: 228-42.

Abdou, Ehaab, Mona Atia, Noha Hussein, Homi Kharas, and Amira Maaty. 2011. "How Can the U.S. and International Finance Institutions Best Engage Egypt's Civil Society?” Brookings Institution Policy Paper, June.

Atia, Mona. 2013. Building a House in Heaven: Pious Neoliberalism and Islamic Charity in Egypt. Minneapolis: University of Minnesota Press.

Baer, Gabriel. 1962. A History of Landownership in Modern Egypt, 1800-1950. London: Oxford University Press.

Baer, Gabriel. 1969. Studies in the Social History of Modern Egypt. Chicago: University of Chicago Press.

Barkan, Ömer Lütfi and Ekrem Hakkı Ayverdi. 1970. İstanbul Vakıfları Tahrir Defteri 953 (1546) Tarihli. Istanbul: Fetih Cemiyeti.

Banfield, Edward C. 1958. The Moral Basis of a Backward Society. Glencoe, Il: Free Press.

Barnes, John Robert. 1986. An Introduction to Religious Foundations in the Ottoman Empire. Leiden: E.J. Brill.

Bayat, Asef. 2002. "Activism and Social Development in the Middle East." International Journal of Middle East Studies 34: 1-28.

Baytal, Yaşar. 2012. Atatürk Döneminde Sosyal Yardım Faaliyetleri (1923-1938). Ankara: Atatürk Araştırma Merkezi.

Behrens-Abouseif, Doris. 2002. "Waqf, in Egypt." Encyclopaedia of Islam, $2^{\text {nd }}$ ed., vol. 11, pp. 63-69. Leiden: Brill.

Berman, Harold J. 1983. Law and Revolution: The Formation of the Western Legal Tradition. Cambridge, MA.: Harvard University Press.

Berque, Jacques. 1974. Maghreb: Histoire et Sociétés. Algiers: SNED, 1974.

Bikmen, Filiz. 2006. The Landscape of Philanthropy and Civil Society in Turkey. Istanbul: Third Sector Foundation of Turkey.

Blaydes, Lisa, and Eric Chaney. 2013. “The Feudal Revolution and Europe's Rise: Political Divergence of the Christian and Muslim Worlds before 1500 CE." American Political Science Review 107: 16-34.

Bosker, Maarten, Eltjo Buringh, and Jan Luiten van Zanden. 2013. "From Baghdad to London: Unraveling Urban Development in Europe, the Middle East, and North Africa, 800-1800." Review of Economics and Statistics 95: 1418-37.

Browers, Michaelle L. 2006. Democracy and Civil Society in Arab Political Thought: Transcultural Possibilities. Syracuse: Syracuse University Press.

Brown, Jonathan A. 2011. "Even If It's Not True It's True: Using Unreliable Hadīths in Sunni Islam." Islamic Law and Society, 18: 1-52.

Buchanan, James M., and Gordon Tullock. 1962. The Calculus of Consent: Logical Foundations of Constitutional Democracy. Ann Arbor: University of Michigan Press.

Caplan, Bryan. 2007. The Myth of the Rational Voter: Why Democracies Choose Bad Policies. Princeton: Princeton University Press. 
Carapico, Sheila. 2012. "Egypt's Civic Revolution Turns 'Democracy Promotion' on Its Head." In Arab Spring in Egypt: Revolution and Beyond, edited by Bahgat Korany and Rabab ElMahdi, pp. 199-222. Cairo: University of Cairo Press.

Chaney, Eric. 2012. "Democratic Change in the Arab World, Past and Present." Brookings Papers in Economic Activity 42: 363-414.

Cole, Juan R. I. 2003. "Al-Tahtawi on Poverty and Welfare." In Poverty and Charity in Middle Eastern Contexts, edited by Michael Bonner, Mine Ener, and Amy Singer, pp. 223-38. Albany: State University of New York Press.

Coleman, James S. 1990. Foundations of Social Theory. Cambridge, Mass.: Harvard University Press.

Crone, Patricia. 2004. God's Rule: Government and Islam. New York: Columbia University Press.

Cunningham, Robert B., and Yasin K. Sarayrah. 1993. Wasta: The Hidden Force in Middle Eastern Society. Westpor, Conn.: Praeger.

Çapa, Mesut. 2009. Kızllay (Hilâl-i Ahmer) Cemiyeti (1914-1925). Ankara: Türk Kızılayı.

Çarkoğlu, Ali. 2006. "Trends in Individual Giving and Foundation Practices." In Philanthropy in Turkey: Citizens, Foundations and the Pursuit of Social Justice, edited by Filiz Bikmen and Rana Zincir, pp. 95-142. Istanbul: Third Sector Foundation of Turkey.

Çizakça, Murat. 2000. A History of Philanthropic Foundations: The Islamic World from the Seventh Century to the Present. Istanbul: Boğaziçi University Press.

Dahl, Robert A. 1989. Democracy and Its Critics. New Haven: Yale University Press.

Deguilhem, Randi. 2004. "On the Nature of Waqf: Pious Foundations in Contemporary Syria." In Les Fondations Pieuses (Waqf) en Méditerranée: Enjeux de Société, Enjeux de Pouvoir, pp. 395-430. Kuwait: Kuwait Awqaf Public Foundation.

Demir, İlhan. 1998. Yeni Vakıfların Temel Kitabı. Ankara: Hu-Der.

Demirel, Ömer. 2000. Sivas Şehir Hayatında Vakıfların Rolü. Ankara: Türk Tarih Kurumu.

Diamond, Larry. 2010. "Why Are There No Arab Democracies?" Journal of Democracy 21: 93104.

El Daly, Marwa. 2007. Philanthropy in Egypt. Cairo: Center for Development Services.

Ellickson, Robert C. 1993. "Property in Land." Yale Law Journal 102: 1315-1400.

Ener, Mine. 2003. Managing Egypt's Poor and the Politics of Benevolence, 1800-1952. Princeton: Princeton University Press.

Findley, Carter V. 1980. Bureaucratic Reform in the Ottoman Empire: The Sublime Porte, 17891922. Princeton: Princeton University Press.

Fish, M. Steven. 2002. "Islam and Authoritarianism." World Politics 55: 4-37.

Fukuyama, Francis. 1995. Trust: The Social Virtues and the Creation of Prosperity. New York: Free Press.

Fung, Archon. 2003. "Associations and Democracy: Between Theories, Hopes, and Realities." Annual Review of Sociology 29: 515-39.

Gerber Haim. 1988. Economy and Society in an Ottoman City: Bursa, 1600-1700. Jerusalem: Hebrew University.

Glaeser, Edward. 2011. Triumph of the City: How Our Greatest Invention Makes Us Richer, Smarter, Greener, Healthier, and Happier. New York: Penguin Press.

Goodwin, Godfrey. 1994. The Janissaries. Northampton, MA: Interlink.

Greif, Avner. 2006. Institutions and the Path to the Modern Economy: Lessons from Medieval Trade. New York: Cambridge University Press. 
Guiso, Luigi, Paola Sapienza, and Luigi Zingales. 2008. "Social Capital as Good Culture.” Journal of the European Economic Association 6: 295-320.

Hansmann, Henry B. 1981. "Reforming Nonprofit Corporation Law." University of Pennsylvania Law Review 129: 497-623.

Hâtemî, Hüseyin Perviz. 1969. Önceki ve Bugünkü Türk Hukukunda Vakıf Kurma Muamelesi. Istanbul: İstanbul Üniversitesi Hukuk Fakültesi.

Hâtemî, Hüseyin. 1979. Medenî Hukuk Tüzelkişileri, Vol. 1. Istanbul: İstanbul Üniversitesi Hukuk Fakültesi.

Hoexter, Miriam. 1998. Endowments, Rulers and Community: Waqf Al-Haramayn in Ottoman Algiers. Leiden: Brill.

Irwin, Robert. 1986. The Middle East in the Middle Ages: The Early Mamluk Sultanate, 12501382. Carbondale: Southern Illinois University Press.

Ismael, Tareq Y. and Jacqueline S. Ismael. 1997. "Civil Society in the Arab World: Historical Traces, Contemporary Vestiges." Arab Studies Quarterly 19: 77-87.

Jamal, Amaney A. 2007. Barriers to Democracy: The Other Side of Social Capital in Palestine and the Arab World. Princeton: Princeton University Press.

Köprülü, Fuad. 1931. "Bizans Müesseselerinin Osmanlı Müesseselerine Tesiri." Türk Hukuk ve İktisat Tarihi Mecmuası 1: 165-313.

Kuran, Timur. 2001. "The Provision of Public Goods under Islamic Law: Origins, Impact, and Limitations of the Waqf System." Law and Society Review 35: 841-97.

Kuran, Timur, ed. 2010-13. Social and Economic Life in Seventeenth-Century Istanbul: Glimpses from Court Records, vols. 5-8. Istanbul: İş Bank Cultural Publications.

Kuran, Timur. 2011. The Long Divergence: How Islamic Law Held Back the Middle East. Princeton, NJ: Princeton University Press.

Kuran, Timur. 2013. "Religious Obstacles to Democratization in the Middle East: Past and Present." Wealth and Well-Being of Nations 5: 17-39.

Kuran, Timur, and Scott Lustig. 2012. "Judicial Biases in Ottoman Istanbul: Islamic Justice and Its Compatibility with Modern Economic Life.” Journal of Law and Economics 55: 63166.

Langohr, Vickie. 2004. "Too Much Civil Society, Too Little Politics: Egypt and Liberalizing Arab Regimes." Comparative Politics 36: 181-204.

Lapidus, Ira. 1988. A History of Islamic Societies. Cambridge: Cambridge University Press.

Leeuwen, Richard van. 1999. Waqfs and Urban Structures: The Case of Ottoman Damascus. Leiden: Brill.

Lev, Yaacov. 2005. Charity, Endowments, and Charitable Institutions in Medieval Islam. Gaineseville: University Press of Florida.

Lewis, Bernard. 1993. Islam in History: Ideas, People, and Events in the Middle East, rev. ed. Chicago: Open Court.

Lewis, Bernard. 2001. The Emergence of Modern Turkey, $3^{\text {rd }}$ ed. New York: Oxford University Press.

Makdisi, George. 1981. The Rise of Colleges: Institutions of Learning in Islam and the West. Edinburgh: Edinburgh University Press.

Mandaville, Jon E. 1979. "Usurious Piety: The Cash Waqf Controversy in the Ottoman Empire." International Journal of Middle East Studies 10: 298-308.

Marsot, Afaf Lutfi al-Sayyid. 1984. Egypt in the Reign of Muhammad Ali. Cambridge: Cambridge University Press. 
Moor, Tine de. 2008. "The Silent Revolution: A New Perspective on the Emergence of Commons, Guilds, and Other Forms of Collective Action in Western Europe." International Review of Social History, special issue on guilds 53: 179-212.

Moore, Barrington, Jr. 1966. Social Origins of Dictatorship and Democracy: Lord and Peasant in the Making of the Modern World. Boston: Beacon Press.

North, Douglass C., John Joseph Wallis, and Barry R. Weingast. 2009. Violence and Social Orders: A Conceptual Framework for Interpreting Recorded History. Cambridge: Cambridge University Press.

Oberauer, Norbert. 2013. "Early Doctrines on Waqf Revisited: The Evolution of Islamic Endowment Law in the $2^{\text {nd }}$ Century AD." Islamic Law and Society 20: 1-47.

Olson, Mancur. 1971. The Logic of Collective Action: Public Goods and the Theory of Groups, rev. ed. Cambridge, Mass.: Harvard University Press.

Öcalan, Hasan Basri, Sevim Sezai, and Doğan Yavaş, editors. 2013. Bursa Vakfiyeleri -1. Bursa: Bursa Büyükşehir Belediyesi.

Özbek, Nadir. 2002. Osmanlı Imparatorluğu’nda Sosyal Devlet: Siyaset, İktidar ve Meşruiyet, 1876-1914. Istanbul: İletişim.

Öztürk, Nazif. 1983. Menşe’i ve Tarihi Gelişimi Açısından Vakıflar. Ankara: vakıflar Genel Müdürlüğ̈̈.

Öztürk, Nazif. 1995. Türk Yenileşme Tarihi Çerçevesinde Vakıf Müessesesi. Ankara: Türkiye Diyanet Vakfi.

Pioppi, Daniela. 2007. "Privatization of Social Services as a Regime Strategy: The Revival of Islamic Endowments (Awkaf) in Egypt." In Debating Arab Authoritarianism: Dynamics and Durability in Nondemocratic Regimes, edited by Oliver Schlumberger, pp. 129-42. Stanford: Stanford University Press.

Pipes, Daniel. 1981. Slave Soldiers and Islam: The Genesis of a Military System. New Haven: Yale University Press.

Putnam, Robert D. 1993. Making Democracy Work: Civic Traditions in Modern Italy. Princeton: Princeton University Press.

Reynolds, Susan. 1997. Kingdoms and Communities in Western Europe 900-1300. Oxford: Oxford University Press.

Rijpma, Auke. 2012. "Funding Public Services through Religious and Charitable Foundations in the Late-Medieval Low Countries." Ph.D. thesis, Utrecht University.

Ross, Michael L. 2001. "Does Oil Hinder Democracy?” World Politics 53: 325-61.

Rubin, Jared. 2011. "Institutions, the Rise of Commerce, and the Persistence of Laws: Interest Restrictions in Islam and Christianity." Economic Journal 121: 1310-39.

Sarıkaya, Makbule. 2011. Türkiye Himaye-i Etfal Cemiyeti, 1921-1935. Ankara: Atatürk Araştırma Merkezi.

Sarkissian, Ani. 2012. "Religious Regulation and the Muslim Democracy Gap." Politics and Religion 5: 501-27.

Schoenblum, Jeffrey A. 1999. "The Role of Legal Doctrine in the Decline of the Islamic Waqf: A Comparison with the Trust." Vanderbilt Journal of Transnational Law 32:1191-227.

Sékaly, Achille. 1929. Le Problème des Wakfs en Égypte. Paris: Reprinted from Révue des Études Islamiques, 1929.

Singer, Amy. 2002. Constructing Ottoman Beneficience: An Imperial Soup Kitchen in Jerusalem. Albany: State University of New York Press. 
Stolle, Dietlind. 2002. "Trusting Strangers-The Concept of Generalized Trust in Perspective." ÖZP 31: 397-412.

Tadmori, Ghazi O., Pratibha Nair, Tasneem Obeid, Mahmoud T. Al Ali, Najib Al Khaja, and Hanan A. Hamamy. 2009. "Consanguinity and Reproductive Health among Arabs." Reproductive Health 6: 17.

Thomas, John Philip. 1987. Private Religious Foundations in the Byzantine Empire. Washington, D.C.: Dumbarton Oaks.

Tilly, Charles. 2005. Contention and Democracy in Europe, 1650-2000. Cambridge: Cambridge University Press.

Tocqueville, Alexis de (1835-40/2000). Democracy in America, translated by Harvey C. Mansfield and Delba Winthrop. Chicago: University of Chicago Press.

Ubicini, M. A. 1853. Lettres sur la Turquie, $2^{\text {nd }}$ ed. Paris: Librairie Militaire de J. Dumaine.

Verbit, Gilbert Paul, translator and editor. 2008. A Ninth Century Treatise on the Law of Trusts (Being a Translation of Al-Khassāf, Ahkām al-Waqū $)$. Philadelphia: Xlibris.

Wiktorowicz, Quintan. 2000. "Civil Society as Social Control." Comparative Politics 33: 43-61.

Yediyıldız, Bahaeddin. 1982. "Vakıf." İslâm Ansiklopedisi 137: 153-72.

Yediyıldız, Bahaeddin. 1984. "XVII. Asır Türk Vakıflarının İktisadî Boyutu." Vakıflar Dergisi 18: 5-42.

Yediyıldı, Bahaeddin. 1990. Institution du Vaqf au XVIIIe Siècle en Turquie: Étude SocioHistorique. Ankara: Éditions Ministère de la Culture.

Yıldırım, Onur. 1999. "Pious Foundations in the Byzantine and Seljuk States: A Comparative Study of Philanthropy in the Mediterranean World during the Late Medieval Era." Rivista Degli Studi Orientali 73: 27-52.

Yom, Sean L. 2005. "Civil Society and Democratization in the Arab World." Middle East Review of International Affairs 9: 14-33.

Zaller, John. 1992. The Nature and Origins of Mass Opinion. Cambridge: Cambridge University Press.

Zanden, Jan Luiten van. 2009. The Long Road to the Industrial Revolution: The European Economy in a Global Perspective, 1000-1800. Leiden: Brill.

Ziblatt, Daniel. 2006. "How Did Europe Democratize?” World Politics 58: 311-38.

Ziujderduijn, Jaco. 2011. "Grave Concerns: Entailment and Intergenerational Agency in Amsterdam (1600-1800)." History of the Family 16: 343-53. 